\title{
OPTIMALISASI KOMPOSISI KANDUNGAN MN PADA FILLER UNTUK MENDAPATKAN KETANGGUHAN DAN KEKERASAN
}

\author{
NUR SUBEKI \\ Jurusan Teknik Mesin, Fakultas Teknik, Universitas Muhammadiyah Malang \\ E-mail: nursubeki@gmail.com
}

\begin{abstract}
ABSTRAK
Submerged Arc Welding (SAW) adalah proses pengelasan yang digunakan dalam fabrikasi pipa, seperti pipa pengelasan spiral. Teknik ini dapat otomatis digunakan dan mempunyai ketahanan tinggi di banyak aplikasi pengelasan. Beberapa faktor mempengaruhi kekuatan dari logam pengelasan sebagai input panas, arus, dan komposisi kimia dari filler, fluks, dan logam dasar. Penelitian lebih lanjut ditujukan untuk meneliti hubungan mikrostruktur-kekerasan dari submerged busur spiral pipa pengelasan. Material yang digunakan pada penelitian ini adalah API 5L X-52 dan API 5LX-60 untuk pipa pengelasan spiral. Pengelasan dilakukan menggunakan tegangan 35 volt, kecepatan pengelasan 13,67 mm/s dimana komposisi Mn pada fluks bervariasi, 1.7; 1.4; 1.4 dengan Mo pada 1.09. Mikrostruktur dan kekerasan dikonduksikan dalam logam dasar, logam pengelasan dan heat affected zone (HAZ). Hasilnya menunjukkan bahwa, peningkatan komposisi Mn dapat meningkatkan struktur besi dalam logam pengelasan. Tingkat kekerasan dan kekuatan meningkat berkorelasi dengan peningkatan jumlah Mn, tetapi untuk komposisi Mn 1.7, tingkat besi menurun, konsekuensinya adalah tingkat kekerasan menurun.
\end{abstract}

Kata kunci: SAW, pipa spiral, mikrostruktur, kekerasan

\begin{abstract}
Submerged Arc Welding (SAW) is a welding process used for fabrication of pipes, for example spiral welded pipes. The technique can be operated automatically and has a high reliability in many various welding applications. Some factors affecting the strength of weld metals are heat input, current, and chemical composition of filler, flux, and base metal. The present investigation aims to study microstructure-hardness relationship of submerged arc spiral welded steel pipes. Material used in this experiment was API 5L X-52 and API 5L X-60 for spiral welded steel pipes. Welding was carried out using voltage of 35 volt, welding speed of 13,67 mm/s whereas composition $M n$ on the flux was varied, 1.7; 1.4; 1.4 with Mo and 1.09. Microstructure and hardness were conducted on base metal, weld metal and heat affected zone (HAZ). Results show that, an increase in composition of Mn could be increases the amount of acicular ferrite structure in weld metal. The hardness and thougness number is increase correlated with increase number of Mn, but for the composition Mn as 1,7, the number of acicular ferrite is decrease, the consequence of hardness number is decrease.
\end{abstract}

Key words: SAW, spiral pipes, microstructure, hardness

\section{PENDAHULUAN}

Pengelasan dengan menggunakan metode Sumerged Arc Welding (SAW) adalah pengelasan yang banyak digunakan untuk penyambungan konstruksi berat, misalnya: jembatan, perpipaan dan bangunan. Luasnya penggunaan metode ini dikarenakan dapat dilakukan secara otomatis dan memiliki keandalan yang tinggi. Struktur mikro dan ketangguhan las dipengaruhi oleh banyak faktor seperti komposisi kimia logam las, input panas, filler, fluks dan lain-lain (Dallam, 1995). Penelitian ini bertujuan untuk menganalisa struktur mikro dan ketangguhan hasil pengelasan SAW pada bahan baja karbon rendah.
Pipa produksi biasanya mengunakan proses pengelasan, salah satu jenis dari pengelasan yang banyak digunakan untuk penyambungan pipa dan memberikan sambungan dalam moderasi kontruksi baja adalah las busur redam atau SAW. Permasalahan yang sering terjadi pada hasil pengelasan SAW pada baja diantaranya adalah timbulnya tegangan sisa dan terbentuknya struktur mikro berupa (martensit, austenit sisa dan karbida) yang dapat menurunkan keuletan atau ketangguhan sehingga tidak memenuhi standart API (American Petrolium Institute). Untuk mengatasi masalah ini pengaruh perlakuan panas stress relief akan berguna untuk meningkatkan ketangguhan las dan ketahanan terhadap laju 
rambat retak fatik pada sambungan pipa spiral baja, (Wiryosumarto dan Okumura, 2000)

Pengaruh kandungan $\mathrm{Mn}$ akan meningkatkan kekuatan tarik dari logam las tersebut. Peningkatan kekuatan tarik ini juga konsisten dengan kekuatan struktur mikro yang terbentuk di mana pada las terdapat ferit acicular yang lebih dominan. Struktur mikro ferit acicular (AF) mempunyai ukuran butir yang kecil, penambahan Mn akan memperhalus (refinement) butir-butir struktur mikro baik pada logam lasan maupun pada daerah reheated. Hubungan antara tegangan luluh dan ukuran butir bias dinyatakan dengan persamaan Hall Petch (Prayoga dan Ilman. 2005). Sambungan las dapat digunakan sebagai sambungan pada konstruksi baja seperti jembatan, bejana tekan, dan perpipaan, harus memenuhi persyaratan yang ketat diantaranya adalah kekuatan tarik dan ketangguhan harus mempunyai nilai yang mendekati logam induknya yaitu $500 \mathrm{MPa}$, (Johnson,dkk).

Persyaratan diatas dapat terpenuhi jika strukturmikro logam las berupa ferit acicular. Harisson dan Farrar (1981), Subeki (2006) melaporkan penelitiannya bahwa ferit acicular dapat meningkatkan kekuatan tarik logam las karena ukuran butirannya kecil, sedangkan ketangguhannya yang baik disebabkan oleh adanya struktur interlocking, Subeki (2006). Namun demikian, terbentuknya ferit acicular pada logam las tidak selalu mudah karena dipengaruhi banyak faktor seperti komposisi logam induk dan logam pengisi, jenis fluks, dan masukan panas. Sementara itu, Gunaraj dan Murugan (2002), melaporkan penelitiannya bahwa efek dari pertambahan heat input akan meningkatkan dimensi weld interface (WI), grain growth zone (GGZ) dan HAZ sehingga memperbesar ukuran weld pool dan luasan peleburan. Disisi lain dengan peningkatan voltase meningkatkan sedeikit lebar WI, GRZ dan HAZ, tetapi lebar GGZ sangat besar peningkatannya.

Didukung oleh Suharno dkk, 2004, yang melaporkan penelitiannya pada pengelasan bahan Baja SM 490 dan Subeki (2006) pada pengelasan pipa spiral, memiliki ketangguhan tertinggi dengan masukan panas $2,12 \mathrm{~kJ} / \mathrm{mm}$ dan pada kuat arus 900 Amper di mana prosentase ferit acikular menunjukkan jumlah yang besar dengan suhu transisi $-7^{\circ} \mathrm{C}$. Hal lain yang berpengaruh misalnya semakin tinggi basicity index dari fluks pada pengelasan baja karbon dengan las busur rendam akan meningkatkan kekuatan logam hasil las (Garland dan Kirkwood, 1976).

\section{METODE}

Hasil proses pengelasan busur rendam sangat tergantung dari pemakaian jenis elektroda dan fluks, arus, tegangan listrik, kecepatan pengelasan dan lain-lain. Pemilihan besar arus dan kecepatan pengelasan yang dipakai dalam pengelasan baja adalah cukup penting, karena faktor tersebut akan menentukan masukan panas (heat input) yang terjadi dan struktur mikro pada daerah las. Pada panelitian ini dipelajari pengaruh besar arus dan kecepatan pengelasan terhadap sifat mekanik (sifat kuat tarik, tekuk, ketangguhan, kekerasan) dan struktur mikro dari hasil pengelasan dengan menggunakan proses pengelasan busur rendam, elektroda dan fluks yang sama terhadap pengelasan dari masing-masing baja API 5L X-52 dan baja SS 400.

Bahan yang akan di pakai adalah Baja API 5L X-60 di mana, Pipa API dengan spesifikasi 5L adalah merupakan spesifikasi yang distandarkan oleh konferensi pembuatan dan pendistribusian dari line pipe untuk minyak, air dan gas dengan kondisi penggunaan yang istimewa, (Iscor, 2000).

Produksi baja untuk line pipe diproduksi dengan electric arc furnace (EAF) atau basic oxygen furnace (BOF) dengan model pengecoran kontinyu. Pipa baja bekerja pada kondisi tidak asam dengan kandungan sulfur maksimum $0,010 \%$. Pada penggunaan pipa dengan ketangguhan yang tinggi dan permukaan yang baik, kalsium pada baja mungkin dapat memperbaiki inklusi sebagai bentuk perbaikan. Parameter pengecoran harus dikontrol dengan hatihati sehingga mendapatkan komposisi kimia yang homogen, struktur yang beragam dan meningkatkan kualitas permukaan.

\section{Pengelasan Submerged Arc Welding}

Submerged arc welding merupakan proses pengelasan otomatis di mana busur listrik dan logam cair tertutup oleh lapisan serbuk fluks, sedangkan kawat pengisi diumpankan secara kontinyu dengan kondisi busur listriknya teredam dalam fluks. Karena panas yang hilang dalam bentuk radiasi sangat kecil maka efisiensi perpindahan panas dari elektroda ke logam las sangat tinggi yaitu sekitar 90\%. Pada pengelasan ini busr listriknya tidak kelihatan maka sangat sulit mengatur jatuhnya ujung busur. Mesin las yang digunakan menggunakan sumberlistrik searah dengan tegangan tetap sehingga dapat mengontrol masukan panas, (Wiryosumarto dan Okumura, 2000)

Dalam proses pengelasan, busur listrik dan proses suplai logam las dari kawat las berlangsung dalam keadaan tertutupi oleh serbuk fluks selama pengelasan busur listrik selain mencairkan ujung kawat las juga ikut mencair sebagian logam induk dan sebagian serbuk fluks. Oleh karena itu selama pembekuan logam las terlindungi oleh terak dan serbuk fluks yang tersisa. 
Keunggulan dari proses pengelasan SAW ini adalah pegelasan ini dapat mengelas pelat-pelat yang tebal-tebal dengan waktu pengelasan yang lebih singkat di banding proses pengelasan lainnya seperti (GTAW atau SMAW). Umumnya proses pengelasan SAW ini sudah semi otomatis, sehingga perencanaan dan persiapan sebelum melakukan proses pengelasan haruslah benar-benar baik untuk mencapai hasil las yang maksimal dan tidak ada cacat las. Untuk mengetahui kualitas dan kemampuan untuk dilas suatu jenis material dengan pengelasan SAW maka dibuatlah prosedur pengelasan. Kemudian dilakukan pengujian di laboratorium mekanik. Dengan mengacu kepada Standar yang berlaku misalnya ASME Section IX dan EN 288 (Standard Procedur Pegelasan Untuk Negara-Negara Persatuan Eropa). Bila pengujian Makro etsa, dan pengujian mekanik (pengujian tarik dan tekuk) memenuhi dua standar yang kita jadikan acuan di atas maka WPS boleh digunakan untuk referensi pengelasan dalam proses produksi sesungguhnya prinsip kerja dari mesin las busur rendam dapat dilihat dari gambar di bawah ini.

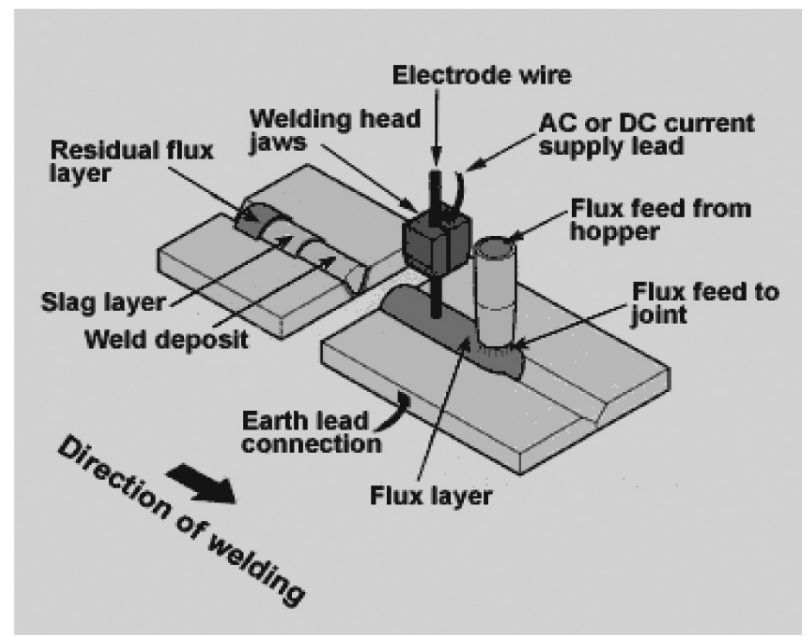

Gambar 1. Skema Las SAW (ASWP, 200)

Kawat Elektroda berbentuk kumparan dengan panjang total bervariasi dari 20 Meter sampai dengan 100 Meter, yang terpasang pada suatu unit Motor pengatur kecepatan. Sehingga kecepatan pengisian Kawat Elektroda tersebut dapat konstan. Kawat Elektroda ini akan melewati Nozzle yang berfungsi sebagai penyearah serta penahan panas.

Cerobong Fluksi berfungsi sebagai tempat penampung fluksi yang pengisiannya dilakukan bersamaan dengan pengisian kawat Elektroda. Dalam hal pengelasan dengan menggunakan kawat Elektroda Tunggal (Single Wire Elektroda). Batang Kawat Elektroda berjalan dan mengalir melalui Kontak Nozzle yang terletak didalam Cerobong yang terisi dengan Fluksi.Busur api terjadi/timbul diantara Kawat Elektroda dan Material Las (Base Metal), yang kemudian akan mencair serta larut bersama. Bersamaan dengan itu sebagian dari Fluksi akan ikut mencair dan setelah mendingin akan disebut dengan Terak. Terak ini akan menutupi serta melindungi cairan logam dan busur api yang terbentuk pada saat proses pengelasan. Sehingga Cairan yang terjadi akan terlindungi dari pengaruh udara luar sampai dengan saat pendinginannya

Fungsi dari fluks adalah sebagai sumber terak untuk melindungi logam cair dari udara sekitarnya, menjaga busur listrik agar tetap stabil, sebagai deoksidator, menghasilkan gas pelindung, mengurangi percikan api dan uap pada pengelasan, serta sebagai sumber dari unsur paduan. Selama proses pengelasan bahan fluks yang digunakan membungkus elektroda mencair dan membentuk terak, kemudian menutupi logam cair yang terkumpul di tempat sambungan dan bekerja sebagai penghalang oksidasi. Dalam beberapa fluks bahannya tidak dapat terbakar tetapi berubah menjadi gas sebagai pelindung dari logam cair terhadap oksidasi dan memantapkan busur.

Di dalam elektroda terbungkus fluks memegang peranan penting karena fluks dapat bertindak sebagai: pemantap busur dan penyebab kelancaran pemindahan butir-butir cairan logam.Sumber terak atau gas yang dapat melindungi logam cair terhadap udara di sekitarnya.

Fluks biasanya terdiri dari bahan-bahan tertentu dengan perbandingan yang tertentu pula. Bahanbahan yang di gunakan dapat di golongkan dalam bahan pemantapan busur, pembuat terak, penghasil gas, deoksidator, unsur paduan dan bahan pengikat. Terdapat 2 macam Fluksi, yaitu: (1) Fused Fluksi terbuat dari campuran butir-butir material seperti Mangaan, Kapur, Boxit, Kwarsa dan Fluorpar didalam suatu Tungku Pemanas. Cairan terak yang terbentuk akan diubah ke dalam bentuk Fluksi dengan jalan: Dituang di suatu cetakan dalam bentuk beberapa lapis/susun yang tebal kemudian dipecah serta disaring sesuai dengan ukuran butiran yang diinginkan. Dari kondisi panas dituang ke dalam air, sehingga timbul percikan-percikan yang kemudian disaring sesuai ukurannya. Metode ini lebih effisien, tetapi kualitas Fluksi yang dihasilkan mengandung Hydrogen yang cukup tinggi yang memerlukan prose lebih lanjut untuk mengurangi kadar Hydrogen tersebut. (2) Bonded Fluksi. Bonded Fluksi ini dibuat di Pabrik dengan jalan mencampur butiran-butiran material yang ukurannya jauh lebih halus seperti mineral, Ferroalloy, Water glass sebagi pengikat dalam suatu Mixer yang khusus. Campuran tersebut kemudian akan dikeringkan dalam suatu Pengering yang berputar pada Temperatur $600-800^{\circ} \mathrm{C}$. 


\section{Mangan (MN)}

Mn termasuk dalam kelompok austenit stabilizer, di mana unsure paduan ini akan menghambat terjadinya transformasi fasa. Sehingga fasa ferit acicular yang memiliki temperatur trasformasi yang rendah dapat terbentuk. Kandungan Mn 1,4-1,8\% wt akan terbentuk struktur ferit acicular yang dominan dan ketangguhan juga meningkat. Sedangkan bila kandungan Mn lebih tinggi akan terbentuk struktur bainit atas dan menurunkan ketangguhan. Penambahan mangan menjamin sifat mampu las yang baik bila kandungannya tidak lebih dari $1.5 \%$.

Molybedenum merupakan logam putih keperakan ditemukan sekitar abad ke 18, memiliki titik lebur dan eleastisitas tinggi dan relatif padat kaku dan kuat daya tahan terhadap thermal shock baik dan daya hantar listrik dan panas baik. Digunakan dalam bentuk mumi $(99.9 \%+$ Mo), dan paduan. Paduan utama adalah TZM (tittanium-zirconiummolybdenum), mengandung sedikit titanium dan zirconium (kurang dari 1\% total). Mo danpaduannya memiliki kekuatan baik pada suhu tinggi, banyak digunakan dalam pelindung panas, element pemanas, elektroda pada resistance welding, dies pada pengerjaan suhu tinggi (die casting molds), dan komponen roket serta jet. Mo digunakan sebagai unsur paduan dalam jumlah besar pada logam refactory lain, dan pada baja superalloys. Sebagai paduan Mo meningkatkan kekuatan, keuletan, dan daya tahan korosi. Kekurangan utama pada paduan Mo adalah daya tahan terhadap oksidasi rendah pada suhu diatas $500^{\circ} \mathrm{C}$ sehingga perlu mengunakan pelapis (coating) pelindung.

\section{Pengujian}

\section{Pengamatan Mikro Struktur}

Penelitian ini menggunakan mikroskop cahaya. Persiapan yang dilakukan sebelum mengamati struktur mikro adalah pengefraisan spesimen, pengampelasan, pemolesan dan pengetsaan. Setelah dipilih, bahan uji diratakan kedua permukaannya dengan menggunakan mesin frais, dalam pendinginan harus selalu terjaga agar tidak timbul panas yang mempengaruhi struktur mikro. Setelah rata digosok dengan menggunakan ampelas mulai dari yang kasar sampai yang halus. Arah pengampelasan tiap tahap harus diubah, pengampelasan yang lama dan penuh kecermatan akan menghasilkan permukaan yang halus dan rata. Bahan yang halus dan rata itu diberi autosol untuk membersihkan noda yang menempel pada bahan. Langkah terakhir sebelum dilihat struktur mikro adalah dengan mencelupkan spesimen kedalam larutan etsa dengan penjepit tahan karat dan permukaan menghadap keatas. Kemudian spesimen dicuci, dikeringkan dan dilihat stuktur mikronya

\section{Pengujian Kekerasan (Hardness)}

Pada penelitian ini dipergunakan metode Rockwell merupakan uji kekerasan dengan pembacaan langsung (direct-reading). Metode ini banyak dipakai dalam industri karena pertimbangan praktis. Variasi dalam beban dan indetor yang digunakan membuat metode ini memiliki banyak macamnya. Metode yang paling umum dipakai adalah Rockwell B (dengan indentor bola baja berdiameter 1/6 inci dan beban $100 \mathrm{~kg}$ ) dan Rockwell C (dengan indentor intan dengan beban $150 \mathrm{~kg}$ ). Walaupun demikian metode Rockwell lainnya juga biasa dipakai. Oleh karenanya skala kekerasan Rockwell suatu material harus dispesifikasikan dengan jelas

Tujuan pengujian kekerasan adalah untuk mengetahui nilai kekerasan pada daerah las. haz butir kasar, haz butir halus, reheated zone butir besar, reheated zone butir kecil, dan logam induk untuk semua hasii pengelasan dengan variasi basicity index fluks.

Bahan penelitian ini : Plat Baja API 5L X60

Spesifikasi pipa : Tebal: $9 \mathrm{~mm}$, panjang: $50.7 \mathrm{~mm}$

Proses Pengelasan : SAW

Jenis elektrode $\quad$ : AWS A5.17-80:EM $12 \mathrm{~K} \emptyset$ $3,2 \mathrm{~mm}$

Jenis flux $\quad$ : OK Flux 10.7 dan OK Flux 10.71

\section{Cara Pengelasan}

Pelat yang berbentuk koil dirol tekuk membentuk pipa spiral dilakukan pengelasan dimulai bagian dalam kemudian pada jarak 1,5 meter dilakukan pengelasan pada bagian luar pipa dengan las SAW seperti terlihat pada gambar. Dari model pengelasan spiral kontinyu yang divariasi adalah pengelasan luar pipa. Prosedur pengelasan adalahmenurut standard AWS A5.17. Pengelasan dilakukan dengan perbedaan variasi Mn dan Mo pada filler Pengelasan dilakukan di PT. KHI Pipe Industries Cilegon Banten. 


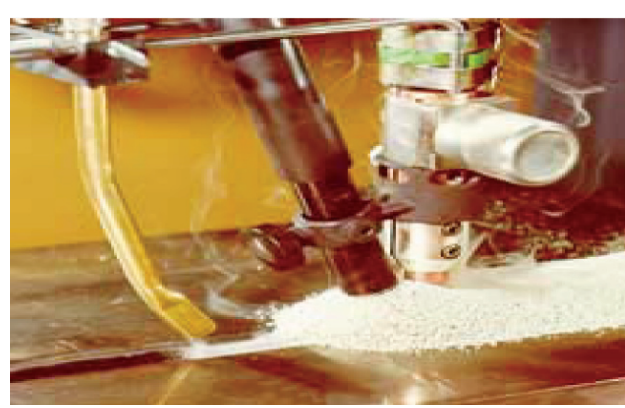

(a)

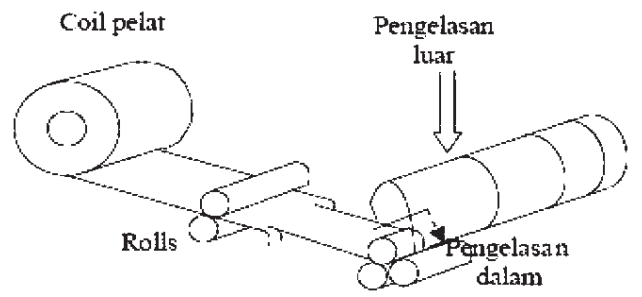

(b)

Gambar 2. a). Proses pengelasan pipa spiral (TWI, 1998) b). Skema pengelasan pipa

\section{Pengamatan Struktur Mikro}

Pengamatan struktur mikro adalah salah satu sifat fisis yang diamati dalam penelitian ini. Tujuan dari pengamatan struktur mikro adalah untuk mengetahui struktur mikro hasil pengelasan dengan variasi kuat arus. Alat yang dipergunakan untuk pengujian ini adalah mikrosokop optik, dengan mikrosokop ini dapat dilihat ukuran dan bentuk butir serta distribusi dari berbagai macam fasa logam serta inklusi yang terjadi pada pengelasan. Pembesaran yang dipergunakan adalah 200 kali. Pengamatan dilakukan pada daerah las, haz dan logam induk

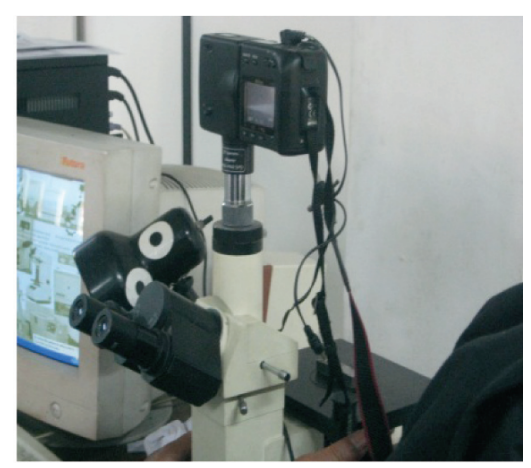

Gambar 3. Alat uji mikro struktur

\section{Langkah-langkah persiapan benda uji: Pengamplasan}

Proses ini dimaksudkan untuk memperkecil kerusakan permukaan yang terjadi akibat proses pengerjaan sebelumnya. Ukuran amplas yang dipergunakan mulai dari kasar yaitu 120, 400, 600, 800, dan 1000.

\section{Pemolesan}

Pemolesan digunakan untuk memperhalus permukaan benda uji sampai mengkilap seperti cermin. Pemolesan dilakukan dengan menggunakan autosol dan digosok dengan kain atau bludru dengan arah sejajar dan pada akhir penggosokan arah melingkar

\section{Pengetsaan}

Tujuan dari mengetsa adalah untuk melarutkan batas butir dari material. Etsa yang digunakan untuk baja karbon adalah HN03 (2,5\%). Proses mengetsa dilakukan dengan cara mencelupkan benda uji kedalam cetsa selama kurang lebih 10-15 detik. Setelah dietsa benda uji dibersihkan dengan sabun colek dan dicuci dengan air kemudian dikeringkan memakai hair dryer.

\section{HASIL DAN PEMBAHASAN}

\section{Komposisi Kimia Pengelasan}

Tabel 1. komposisi kandungan kimia filler untuk material 1

\begin{tabular}{cccccc}
\hline $\mathbf{C}$ & $\mathbf{S i}$ & $\mathbf{M n}$ & $\mathbf{C r}$ & $\mathbf{N i}$ & $\mathbf{M o}$ \\
\hline 0,05 & 0,5 & 1,7 & - & - & - \\
\hline
\end{tabular}

Tabel 2. komposisi kandungan kimia filler untuk material 2

\begin{tabular}{cccccc}
\hline $\mathbf{C}$ & $\mathbf{S i}$ & $\mathbf{M n}$ & $\mathbf{C r}$ & $\mathbf{N i}$ & Mo \\
\hline 0,5 & 0,50 & 1,4 & - & - & - \\
\hline
\end{tabular}

Tabel 3. komposisi kandungan kimia filler untuk material 3

\begin{tabular}{cccccc}
\hline $\mathbf{C}$ & $\mathbf{S i}$ & $\mathbf{M n}$ & $\mathbf{C r}$ & $\mathbf{N i}$ & Mo \\
\hline 0,5 & 0,40 & 1,4 & - & - & 0,5 \\
\hline
\end{tabular}

Tabel 4. komposisi kandungan kimia filler untuk meaterial 4

\begin{tabular}{cccccc}
\hline $\mathbf{C}$ & $\mathbf{S i}$ & $\mathbf{M n}$ & $\mathbf{C r}$ & $\mathbf{N i}$ & Mo \\
\hline 0,11 & 0,29 & 1,09 & 0,03 & 0,02 & 0,01 \\
\hline
\end{tabular}

\section{PENGAMATAN FOTO MAKRO}

Foto makro dimaksukkan untuk mengetahui bentuk dan batas antara daerah las, HAZ, logam induk, las bagian luar dan las bagian dalam. Pada pengelasan pipa faktor yang paling dominan adalah kekuatan yang terdapat pada pengelasan bagian luar, dari gambar 3 terlihat bahwa daerah las luar lebih besar dari pada yang dalam, sementara daerah 
HAZ sangat tipis, ini menunjukkan bahwa daerah pengaruh panas memiliki area yang semoit.

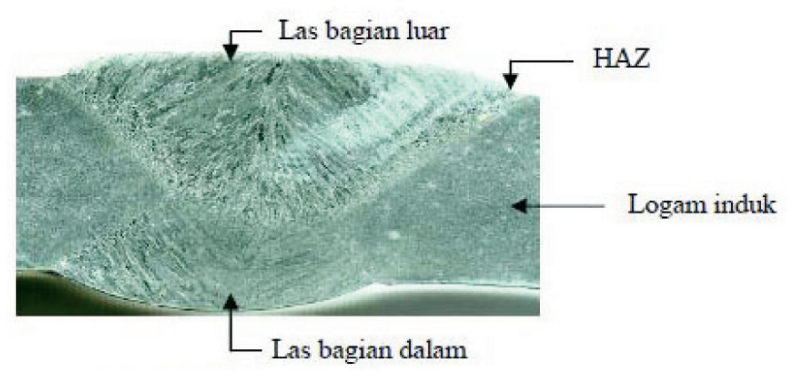

Gambar 4. foto makro las

\section{PENGAMATAN STRUKTUR MIKRO}

\section{Struktur Mikro Bagian Las}

Pengujian struktur mikro dimaksudkan untuk mengetahui bentuk, susunan dan ukuran butir pada logam las. Struktur mikro logam las ditentukan oleh banyak faktor diantaranya masukan panas, kuat arus, kandungan dan komposisi dari filler dan fluks, kecepatan las dan laju pendinginan. Pada gambar 4 ditunjukkan bentuk struktur mikro berdasarkan perbedaan kandungan Mn nya yitu mulai dari material 1 dengan kandungan Mn 1.7, material 2 dengan kandungan Mn 1.4, material 3 dengan kandungan Mn 1.4, material 4 dengan kandungan Mn 1.09. Hal ini digunakan untuk menentukan struktur mikro yang dominan pada perubahan kandungan Mn yang berfungsi untuk meningkatkan sifat mekanik sambungan las.

Kandungan Mn pada Filler dapat menentukan kualitas dari pengelasan, hal ini terlihat dari gambar 4 yang menunjukkan bentuk struktur mikro pada bagian Las. Pada gambar 4a menunjukan struktur mikro yang terbentuk didominasi oleh ferit batas butir, disusul dengan acicular ferit dan ferit Widmanstaten sehingga pengelasan yang tebentuk masih mudah dibentuk namun ketangguhan kurang baik. Pada gambar 4b Didominasi oleh ferit Widmanstaten disusul dengan ferit batas butir dan acicular ferit, mikrostuktur dengan komposisi ini menunjukkan hasil pengelasan ini masih memiliki sifat mampu bentuk karena kekerasanya dan ketangguhannya masih rendah Pada gambar 4c menunjukkan mikrostruktur yang terbentuk didominasi oleh ferit acicular disusul dengan ferit Widmanstaten dan ferit batas butir, kondisi ini dapat diartikan bahwa sifat pengelasan yang dihasilkan memiliki ketangguhan dan kekerasan yang baik, sehingga mampu menahan rambatan retak fatik $4 \mathrm{~d}$ menunjukkan struktur mikro yang terbentuk didominasi Ferit acikular disusul dengan ferit Widmanstaten dan ferit batas a). Material $1 \mathrm{Mn} 1.7$

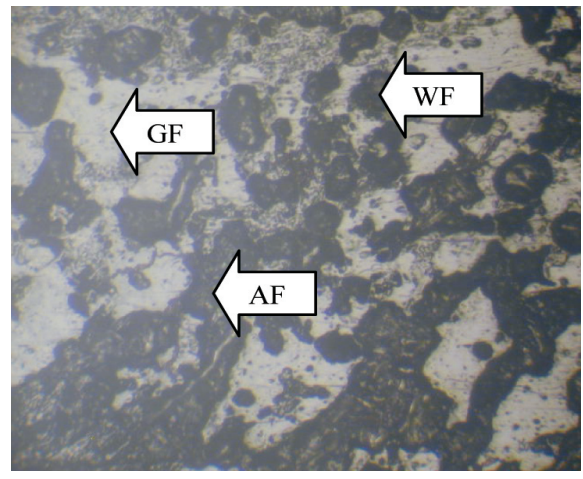

c). Material $3 \mathrm{Mn} 1.4$ dan Mo 0.5

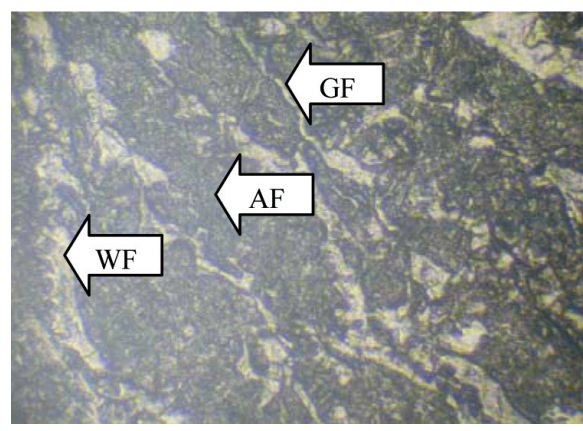

b). Material $2 \mathrm{Mn} 1.4$

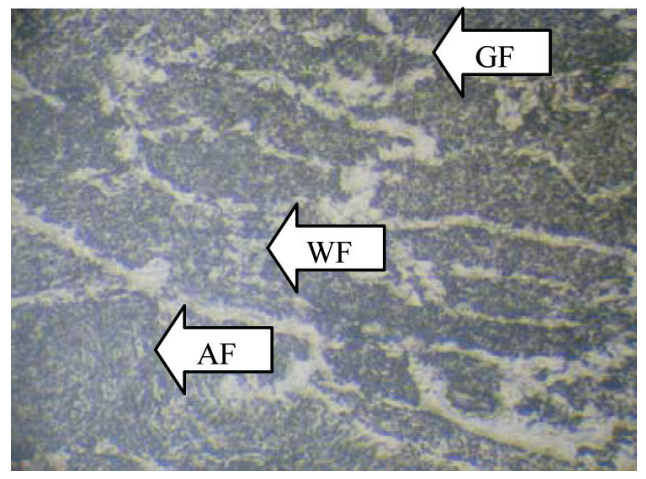

d). Material 4 Mn 0.9 dan Mo 0.01

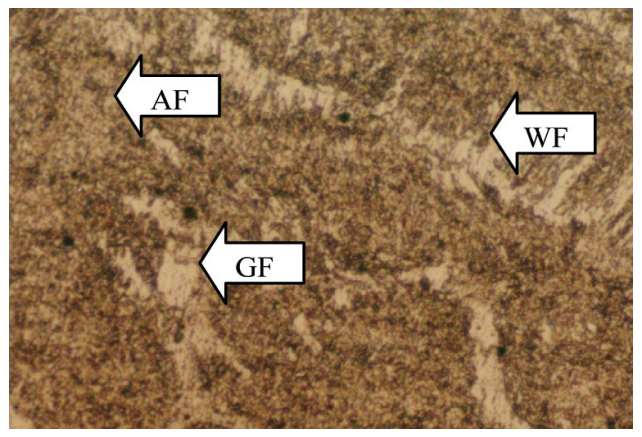

Gambar 5. Foto mikro daerah las AF: Acicular Ferit, GF: Ferit Batas Butir WF: Ferit Witmanstaten 

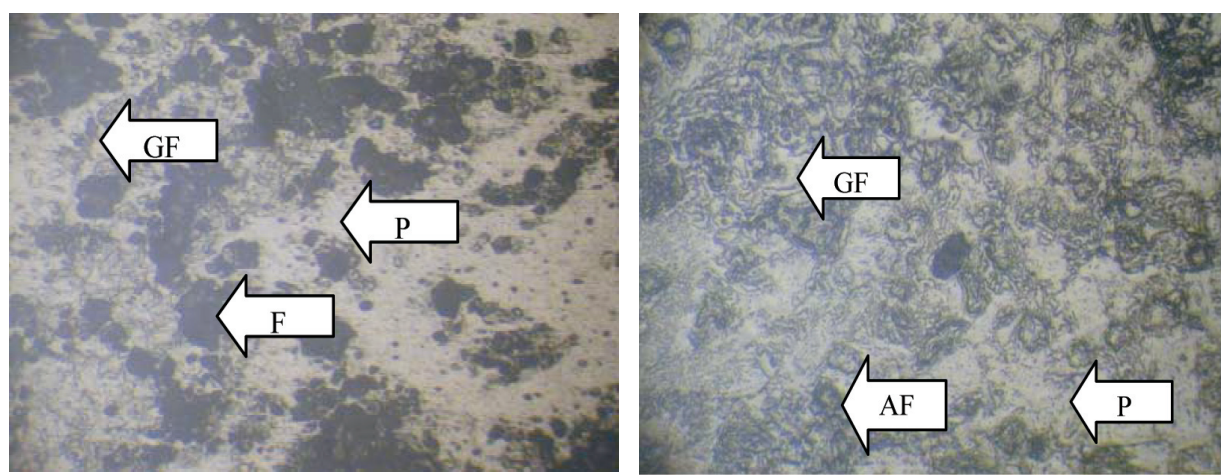

c). Material 3 Mn 1.4 dan Mo 0.5

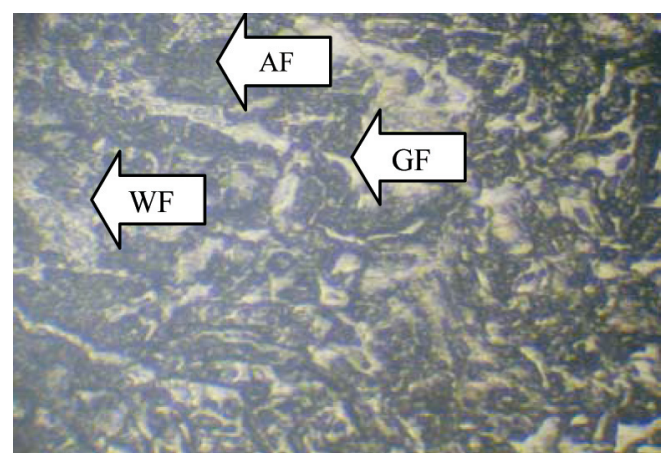

Gambar 6. Foto mikro daerah HAZ

AF: Acicular Ferit, GF: Ferit Batas Butir WF: Ferit Witmanstaten

butir, kondisi menunjukkan bahwa untuk hasil pengelasan ini juga memilki ketangguhan dan kekerasan yang baik.

\section{Struktur mikro bagian HAZ}

Pengaruh kandungan Mn pada filler terhadap pengelsan SAW pada struktur mikro bagian HAZ terlihat pada gambar 5. pada gambar 5a daerah HAZ menunjukkan bahwa struktur mikro yang terbentuk di dominasi oleh perlit disusul dengan ferit batas butir dan acicular ferit, ini artinya daerah tersebut sangat lunak. Gambar 5b pada daerah HAZ struktur mikro yang terbentuk didominasi oleh struktur mikro ferit batas butir disusul dengan acicular ferit dan perlit, kondisi ini berarti sifat daerah tersebut agak keras dan lebih tangguh. Pada gambar 5c pada derah HAZ menunjukkan bahwa prosentase acicular ferit cukup besar disusul dengan ferit acicular disusul dengan ferit Widmanstaten dan ferit batas butir, kondisi menunjukan hasil pengelasan didaerah HAZ ini memiliki sifat mekanik yang sangat bagus diantaranya kekuatan, ketangguhan dan kekerasan.

\section{Pengamatan SEM}

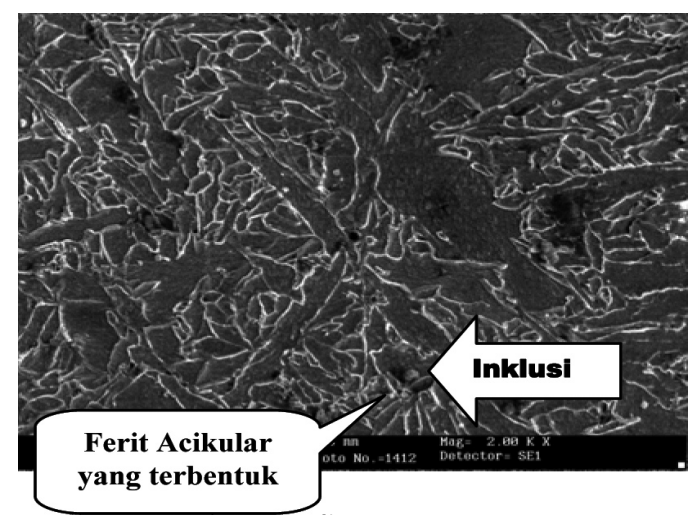

Gambar 7. Foto SEM logam las dengan terbentuknya struktur ferit acicular

Struktur mikro ferit acicular terbentuk pada hasil pengelasan dimulai dari adanya inklusi dan kemudian membentuk nucleus-nucleus yang kemudian memanjang membentuk struktur ferit acicular (Bhadeshia, 2001). Struktur dan bentuk inklusi dapat di amati mengunakan SEM seperti terlihat pada gambar 6 . 
Pengertian inklusi adalah partikel halus dengan ukuran sekitar $0,2-1 \mu \mathrm{m}$ yang terbentuk dari hasil reaksi oksidasi atau reduksi selama proses pengelasan, tetapi partikel tersebut tidak ikut larut dalam logam cair.

Data distribusi dan ukuran inklusi dapat diperoleh dengan pengujian SEM sedangkan komposisi kimianya dengan EDX-Ray spectrometer (energy dispersive $X$-Ray).

Adanya inklusi yang banyak seperti yang terjadi pada logam las menyebabkan butir austenit menjadi kecil karena inklusi menghambat pertumbuhan butir selama transformasi dari $\delta \rightarrow \gamma$ sehingga pada saat terjadi transfomasi dari $\gamma \rightarrow \alpha$ struktur mikro yang terbentuk adalah ferit batasbutir dan ferit Widmanstatten (Harrison, 1981).

\section{Pengujian Kekerasan}

Pengujian kekerasan yang digunakan dengan metode rockwel dengan penggunaan beban $150 \mathrm{~kg}$, beban tersebut dipilih untuk mendapatkan bekas indentasi yang kecil sehingga mendapatkan jarak pengujian yang rapat, sehingga tiap titik perubahan akan dapat diukur nilai kekerasannya.

Dari hasil pengujian kekerasan telah diperoleh data untuk daerah las, haz, dan logam induk dengan menggunkan beban $150 \mathrm{~kg}$ dan waktu 15 detik. tiap material mempunyai perbedaan kandungan $\mathrm{Mn}$ pada Flux pengelasan.

Tabel 5. Data Nilai Kekerasan

\begin{tabular}{|c|c|c|c|}
\hline Spesimen & $\begin{array}{c}\text { Logam } \\
\text { Induk }\end{array}$ & Haz & Las \\
\hline \multirow[t]{5}{*}{ Material 1} & 43 & 45 & 44 \\
\hline & 43 & 43 & 45 \\
\hline & 44 & 44 & 44 \\
\hline & 45 & 44 & 44 \\
\hline & 43 & 43.5 & 44.5 \\
\hline \multirow[t]{5}{*}{ Material 2} & 47.5 & 47 & 48 \\
\hline & 47 & 46.5 & 48 \\
\hline & 47.5 & 47.5 & 46.5 \\
\hline & 46 & 46 & 47 \\
\hline & 46 & 47 & 47.5 \\
\hline \multirow[t]{5}{*}{ Material 3} & 49.5 & 47 & 49 \\
\hline & 49.5 & 47.5 & 49 \\
\hline & 49 & 47 & 48.5 \\
\hline & 48 & 47 & 47 \\
\hline & 47 & 47.5 & 46 \\
\hline \multirow[t]{5}{*}{ Material 4} & 48 & 46.5 & 48 \\
\hline & 48 & 46.5 & 47.5 \\
\hline & 47.5 & 46 & 49 \\
\hline & 48 & 45.5 & 48 \\
\hline & 48 & 47 & 49 \\
\hline
\end{tabular}

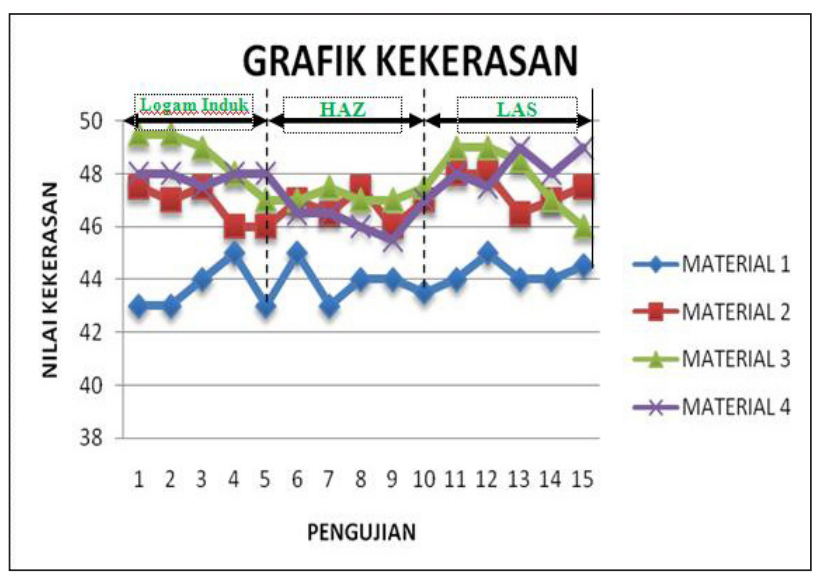

Gambar 8. Grafik kekrasan

Tabel 6. Data nilai kekerasan pada daerah haz

\begin{tabular}{|c|c|c|c|c|}
\hline Material & $\begin{array}{c}\text { Material } \\
1 \\
\text { Mn } 1.7\end{array}$ & $\begin{array}{c}\text { Material } \\
2 \\
\text { Mn } 1.4\end{array}$ & $\begin{array}{c}\text { Material } \\
3 \\
\text { Mn } 1.4 \\
\text { Mo } 0.5 \\
\end{array}$ & $\begin{array}{c}\text { Material } \\
4 \\
\text { Mn } 1.09 \\
\text { Mo } 0.01 \\
\end{array}$ \\
\hline \multirow{5}{*}{$\begin{array}{l}\text { Baja API } \\
5 \mathrm{~L} \mathrm{X-60}\end{array}$} & 45 & 47 & 47 & 46.5 \\
\hline & 43 & 46.5 & 47.5 & 46.5 \\
\hline & 44 & 47.5 & 47 & 46 \\
\hline & 44 & 46 & 47 & 45.5 \\
\hline & 43.5 & 47 & 47.5 & 47 \\
\hline
\end{tabular}

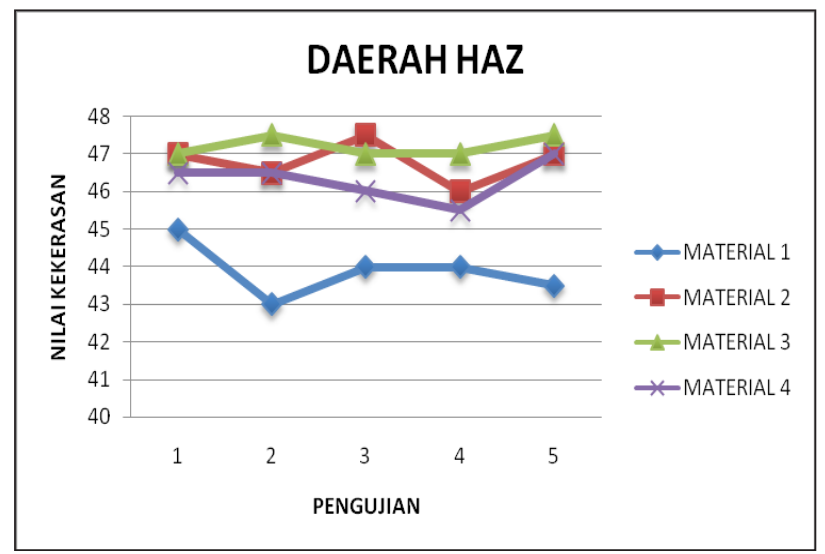

Gambar 9. Grafik kekerasan pada daerah HAZ

Pada daerah HAZ Nampak pada gambar 8 bahwa nilai kekerasan yang pailing tinggi terdapat di material dengan kandungan Mn 1.4 dengan penambahan Mo, disusul dengan mateal las dengan kandungan Mn 1.4, kemudian 1.09 dan terendah adalah kandungan Mn 1.7. 
Tabel 7. Data nilai kekerasan pada derah las

\begin{tabular}{|c|c|c|c|c|}
\hline Material & $\begin{array}{c}\text { Material } \\
1 \\
\text { Mn } 1.7\end{array}$ & $\begin{array}{c}\text { Material } \\
2 \\
\text { Mn } 1.4\end{array}$ & $\begin{array}{c}\text { Material } \\
3 \\
\text { Mn } 1.4 \\
\text { Mo 0.5 } \\
\end{array}$ & $\begin{array}{c}\text { Material } \\
4 \\
\text { Mn 1.09 } \\
\text { Mo0.01 } \\
\end{array}$ \\
\hline \multirow{5}{*}{$\begin{array}{l}\text { Baja API } \\
\text { 5L X-60 }\end{array}$} & 44 & 48 & 49 & 48 \\
\hline & 45 & 48 & 49 & 47.5 \\
\hline & 44 & 46.5 & 48.5 & 49 \\
\hline & 44 & 47 & 47 & 48 \\
\hline & 44.5 & 47.5 & 46 & 49 \\
\hline
\end{tabular}

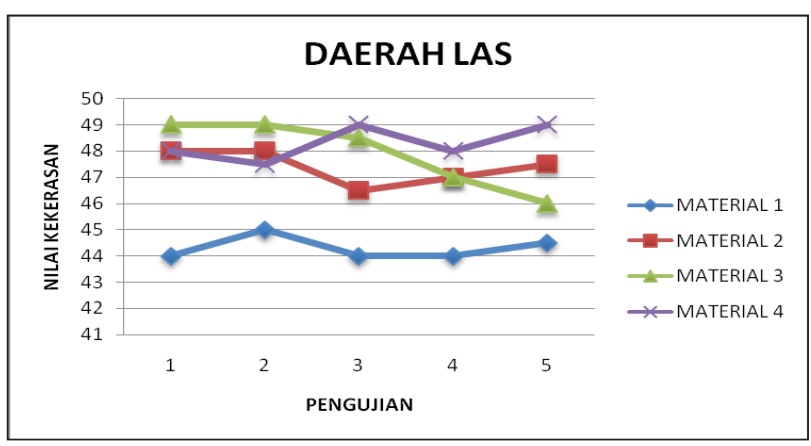

Gambar 10. Grafik keakerasan daerah LAS

Pada derah LAS nbilai kekerasan yang apaling tinggi terdapat pada material dengan kom posisi Mn 1.4 dan Mo 0.5 sementara nilai kekrasan yang paling rendah terdapat pada material dengan komposisi $\mathrm{Mn}$ 1.7. Hal ini menunjukkan bahwa penambahan Mn selalu meningkatkan ketangguhan.

Tabel 8. nilai rata-rata pengujian kekerasan pada masing-masing material

\begin{tabular}{|c|c|c|c|c|}
\hline Daerah & $\begin{array}{c}\text { Material } 1 \\
\text { Mn 1.7 }\end{array}$ & $\begin{array}{c}\text { Material } 2 \\
\text { Mn 1.4 }\end{array}$ & $\begin{array}{c}\text { Material } \\
\text { Mn 1.4 } \\
\text { Mo 0.5 } \\
\end{array}$ & $\begin{array}{c}\text { Material 4 } \\
\text { Mn 1.09 } \\
\text { Mo 0.01 } \\
\end{array}$ \\
\hline Logam Induk & 43.6 & 46.8 & 48.6 & 47.9 \\
\hline HAZ & 43.9 & 46.8 & 47.2 & 46.3 \\
\hline LAS & 44.3 & 47.7 & 47.9 & 48.3 \\
\hline
\end{tabular}

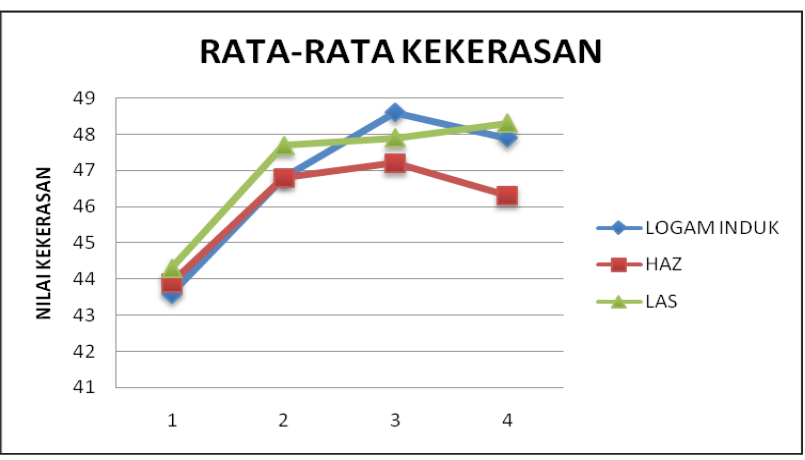

Gambar 11. Grafik Nilai Rata-Rata Kekerasan Untuk Masing-Masing Material

Dari gambar 11 pada material 3 mempunyai kekerasan yang paling tinggi di daerah las dan derah haz, dan untuk material 1 mempunyai nilai kekerasan yang paling rendah pada derah las dan haz

\section{SIMPULAN}

Pada pengamatan mikrostruktur didapatkan bahwa peningkatan kandungan $\mathrm{Mn}$ pada filler dapat meningkatkan jumlah struktur acicular ferit sihingga ketangguhan material las meningkat. Namun pada kandungan Mn 1.7 justru struktur yang terbentu memunculkan banyak perlit, sehingga menurunkan ketangguhan logam hasil las. Pada pengujian kekerasan menunjukkan bahwa kandungan Mn pada komposisi 1.4 yang ditambah dengan Mo memiliki kekerasan yang paling tingi sementara Mn tertinggi yaitu 1.7 ternyata memiliki nilai kekerasan yang rendah

\section{DAFTAR PUSTAKA}

Bhadeshia, H.K.D.H., dan Svensson, L. 1991. Modelling the Evolution of Microstucture in Steel Weld Metal, IIW DOC II-A-846-1991.

Dallam, C.B., Liu, S., dan olson, D.L. 1985. Flux Composition Dependence of Microstructure and Tougness of Submerged Arc HSLA Weldments, Welding Journal 64, pp. 140-151.

Garland, J.G., dan Kirwood, P.R. 1975. Metal Construction, May, pp 275-283.

Gunaraj, V, and Murugan, N. 2002. Prediction of HeatAffected Zone Characteristics in Submerged Arc Welding of Structural Steel Pipes. Welding Journal, pp 94S-910 S. 
Harrison, P.L, dan Farrar, R.A. 1981. Influence of Oxigenrich Inclusions on the $\gamma$ a Phase Transformation in High Strength Low Alloy (HSLA) Steel Weld Metals, Journal of Material Science, 16, pp 2218-2226.

Iscor Ltd. 2000. Hot Rolled Strip for Line Pipe, PO Box 2, Vanderbijlpark.

Prayoga, B.T dan Ilman, M.N. 2006. Analisis Kekeuatan Tarik dan Ketangguhan Kekeuatan Las Busur Redam Baja Karbon Rendah Dengan Variasi Kandungan Mn”, Forum Teknik Volume 30. No. 1, Yokyakarta.

Subeki. 2006. Pengaruh Kuat Arus Terhadap Kekuatan Dan Kekerasan Sambungan Las Busur Terendam (Submerged Arc Welding) Pada Pengelasan Pipa Spiral Baja Api 5l X-52, PBI, UMM Malang.
Subeki. 2006. Nilai Ketangguhan Dan Bentuk Struktur Mikro Dari Perubahan Kuat Arus Pengelasan Pipa Spiral, PBI, UMM Malang.

Subeki. 2007. Optimalisasi Nilai Ketangguhan dan Bentuk Perpatahan pada Pengelasan Busur Terendam Pipa Spiral Baja API 5L X 52, Optimum Vol. 7, Hal 107-208, Malang.

Suharno, Ilman, M.N., dan Jamasri. 2004. Pengaruh Heat Input terhadap Ketangguhan dan Laju Rambatan Retak Fatik pada Pengelasan Baja SM 490, Tesis S2, UGM. Yokyakarta.

Wiryosumarto, H., dan Okumura, T. 2000. Teknologi Pengelasan Logam, PT Pradnya Paramita, Jakarta. 